\title{
¿INDEPENDENCIA JUDICIAL? DEPENDE... (SENTENCIA DEL TRIBUNAL CONSTITUCIONAL SOBRE LOS TRIBUNALES TRIBUTARIOS Y ADUANEROS)
}

\author{
Comentario de Andrés Bordali Salamanca
}

Santiago, treinta de diciembre de dos mil ocho.

\section{VISTOS Y CONSIDERANDO:}

PRIMERO. Que por oficio N 7.709, de 30 de septiembre de 2008, la Cámara de Diputados ha enviado el proyecto de ley, aprobado por el Congreso Nacional, que fortalece y perfecciona la jurisdicción tributaria a fin de que este Tribunal, en conformidad a lo dispuesto en el artículo 93, inciso primero, $\mathrm{N}^{\circ} 1^{\circ}$, de la Constitución Política de la República, ejerza el control de constitucionalidad de los artículos $1^{\circ}, 3^{\circ}$ a 12,14 , 16, en lo relativo a los jueces, 17 y 25 del artículo primero; de los números 7), 8), 11), 14), 15), 16), 31), 32), 39), 41), 44), respecto del inciso primero del artículo 155, 48), letras a) y g), 49), letras b), c) y d), y 50), letras c) y g), del artículo segundo; de los números 2), 3), 5), artículos 117 a 119, 129 D y 129 K, 8), letra a), 12) y 13), letra a), del artículo tercero; de los números 1), letra a), 2), 3) y 4) del artículo quinto; de los artículos sexto y octavo permanentes y de los artículos $1^{\circ}, 2^{\circ}, 3^{\circ}$ a $5^{\circ}, 9^{\circ}$, letra b), y 10 transitorios del mismo;

SEGUNDO. Que el artículo 93, inciso primero, $\mathrm{N}^{\circ} 1^{\circ}$, de la Constitución Política establece que es atribución de este Tribunal: "Ejercer el control de constitucionalidad de las leyes que interpreten algún precepto de la Constitución, de las leyes orgánicas constitucionales y de las normas de un tratado que versen sobre materias propias de estas últimas, antes de su promulgación";

TERCERO. Que el artículo 77 de la Carta Fundamental dispone:

"Una ley orgánica constitucional determinará la organización y atribuciones de los tribunales que fueren necesarios para la pronta y cumplida administración de justicia en todo el territorio de la República. La misma ley señalará las calidades que respectivamente deban tener los jueces y el número de años que deban haber ejercido la profesión de abogado las personas que fueren nombradas ministros de Corte o jueces letrados.

La ley orgánica constitucional relativa a la organización y atribuciones de los tribunales, sólo podrá ser modificada oyendo previamente a la Corte Suprema de conformidad a lo establecido en la ley orgánica constitucional respectiva. 
La Corte Suprema deberá pronunciarse dentro del plazo de treinta días contados desde la recepción del oficio en que se solicita la opinión pertinente.

Sin embargo, si el Presidente de la República hubiere hecho presente una urgencia al proyecto consultado, se comunicará esta circunstancia a la Corte.

En dicho caso, la Corte deberá evacuar la consulta dentro del plazo que implique la urgencia respectiva.

Si la Corte Suprema no emitiere opinión dentro de los plazos aludidos, se tendrá por evacuado el trámite.

La ley orgánica constitucional relativa a la organización y atribuciones de los tribunales, así como las leyes procesales que regulen un sistema de enjuiciamiento, podrán fijar fechas diferentes para su entrada en vigencia en las diversas regiones del territorio nacional. Sin perjuicio de lo anterior, el plazo para la entrada en vigor de dichas leyes en todo el país no podrá ser superior a cuatro años.";

CUARTO. Que las disposiciones del proyecto remitido sometidas a control de constitucionalidad establecen:

“ARTÍCULO PRIMERO. Fíjase el siguiente texto de la Ley Orgánica de Tribunales Tributarios y Aduaneros:

Artículo $1^{\circ}$. Los Tribunales Tributarios y Aduaneros son órganos jurisdiccionales letrados, especiales e independientes en el ejercicio de su ministerio, cuyas funciones, en el ámbito de su territorio, son:

$1^{\circ}$. Resolver las reclamaciones que presenten los contribuyentes, de conformidad al Libro Tercero del Código Tributario.

$2^{\circ}$. Conocer y fallar las denuncias a que se refiere el artículo 161 del Código Tributario y los reclamos por denuncias o giros contemplados en el número tercero del artículo 165 del mismo cuerpo legal.

$3^{\circ}$. Resolver las reclamaciones presentadas conforme al Título VI del Libro II de la Ordenanza de Aduanas y las que se interpongan de acuerdo a lo dispuesto en los artículos 186 y 187 de esa Ordenanza.

$4^{\circ}$. Disponer, en los fallos que se dicten, la devolución y pago de las sumas solucionadas indebidamente o en exceso a título de impuestos, reajustes, intereses, sanciones, costas u otros gravámenes.

$5^{\circ}$. Resolver las incidencias que se promuevan durante la gestión de cumplimiento administrativo de las sentencias.

$6^{\circ}$. Conocer del procedimiento especial de reclamo por vulneración de derechos a que se refiere el Párrafo $2^{\circ}$ del Título III del Libro Tercero del Código Tributario.

$7^{\circ}$. Conocer del procedimiento especial de reclamo por vulneración de derechos establecido en el Párrafo 4 del Título VI del Libro II de la Ordenanza de Aduanas.

$8^{\circ}$. Conocer de las demás materias que señale la ley. 
Artículo $5^{\circ}$. El Juez Tributario y Aduanero y el Secretario Abogado del Tribunal Tributario y Aduanero serán nombrados por el Presidente de la República, de una terna propuesta por la respectiva Corte de Apelaciones.

La Corte formará la terna correspondiente de una lista de un mínimo de cinco y un máximo de diez nombres, que le será propuesta por el Consejo de Alta Dirección Pública con sujeción al procedimiento establecido para el nombramiento de altos directivos públicos del primer nivel jerárquico, contenido en el Párrafo $3^{\circ}$ del Título VI de la ley $\mathrm{N}^{\mathrm{o}}$ 19.882, con las modificaciones siguientes:

a) El perfil profesional de competencias y aptitudes del cargo concursado será definido por el Consejo.

b) De no haber al menos cinco candidatos al cargo que cumplan los requisitos para integrar la nómina, el Consejo podrá ordenar que se efectúe un nuevo concurso para conformar o completar la lista, según corresponda.

La Corte de Apelaciones respectiva podrá rechazar, en forma fundada y por una sola vez, todos o algunos de los nombres contenidos en la lista que se le presente. Si el número de nombres restantes fuere inferior a cinco, la Corte comunicará el hecho al Consejo, para que complete la nómina llamando a un nuevo concurso, en el cual no podrán participar las personas que fueron rechazadas.

Para conformar la terna para el cargo de juez tributario y aduanero, los postulantes deberán ser recibidos por el pleno de la Corte de Apelaciones en una audiencia pública citada especialmente al efecto. Cada Corte establecerá la forma en que se desarrollará esta audiencia.

El resto del personal de los Tribunales Tributarios y Aduaneros será nombrado por el Presidente de la Corte de Apelaciones respectiva, previo concurso público efectuado conforme a las normas del Párrafo $1^{\circ}$ del Título II de ley $\mathrm{N}^{\circ} 18.834$, que aprueba el Estatuto Administrativo, cuyo texto refundido, coordinado y sistematizado fue fijado por el decreto con fuerza de ley $\mathrm{N}^{\circ} 29$, de 2005, del Ministerio de Hacienda,. Las funciones que el artículo 21 de dicho cuerpo legal asigna al Comité de Selección serán desempeñadas por la Unidad Administradora a que se refiere el Título II de la presente ley.

[Continúa texto del proyecto de ley]

QUINTO. Que, de acuerdo al considerando segundo, corresponde a este Tribunal pronunciarse sobre las normas del proyecto remitido que estén comprendidas dentro de las materias que el Constituyente ha reservado a una ley orgánica constitucional;

SEXTO. Que las disposiciones comprendidas en los artículos $1^{\circ}, 3^{\circ}, 4^{\circ}$, inciso primero, $5^{\circ}, 6^{\circ}, 7^{\circ}, 8^{\circ}, 9^{\circ}, 10,11,12,14$ y 16 en lo relativo a los jueces, del artículo primero; en los números 7), 8), 11), 14), 15), 16), 31), 32), 39), 41), 44) respecto del inciso primero del artículo 155, 48), letras a) y g), 49), letras b), c) y d), y 50), letras c) y g), del artículo segundo; en los números 2), 3), 5) en relación con los artículos 117 , 118, 119, 129 D y $129 \mathrm{~K}$, incisos primero y tercero, 8), letra a), 12) y 13), letra a), del artículo tercero; en los números 1), letra a), 2), 3) y 4), del artículo quinto; en el 
artículo sexto y en el artículo octavo permanentes; y en los artículos primero, segundo, tercero, cuarto, quinto y décimo transitorios del proyecto en análisis forman parte de la ley orgánica constitucional a que alude el artículo 77 de la Carta Fundamental, puesto que se refieren a la organización y atribuciones de los Tribunales Tributarios y Aduaneros que se crean como órganos jurisdiccionales especiales e independientes por el artículo $1^{\circ}$ del artículo primero del mismo;

SEPTIMO. Que las disposiciones contenidas en los artículos $4^{\circ}$, inciso final, 17 y 25 del artículo primero; en el número 5) respecto al artículo $129 \mathrm{~K}$, inciso segundo, del artículo tercero; y en el artículo $9^{\circ}$ transitorio, letra b), no regulan materias propias de ley orgánica constitucional, motivo por el cual no le corresponde a este Tribunal pronunciarse sobre ellas;

OCTAVO. Que no obstante que la Cámara de origen ha sometido a control preventivo de constitucionalidad sólo el inciso primero del artículo 155 que el No 44) del artículo segundo del proyecto en estudio incorpora al Código Tributario, esta Magistratura, como lo ha señalado en numerosas ocasiones, para cumplir cabalmente con la función que le asigna el artículo 93, inciso primero, $\mathrm{N}^{\circ} 1^{\circ}$, de la Carta Fundamental, ha de entrar a analizar dicho artículo en su totalidad, en atención a que sólo un examen de ese carácter permite determinar el alcance de sus disposiciones y, en consecuencia, la naturaleza que tienen;

NOVENO. Que del estudio del precepto antes indicado en su integridad se desprende que su inciso tercero configura con su inciso primero, sujeto a control, un todo armónico e indisoluble que no es posible separar, razón por la cual forma parte, de igual modo, de la ley orgánica constitucional contemplada en el artículo 77 de la Constitución;

DECIMO. Que no ocurre lo mismo con el inciso segundo del artículo 155 en análisis, el cual, si bien es cierto guarda relación con los incisos primero y tercero del mismo, se refiere a una materia distinta que no queda comprendida dentro de aquellas que son propias de la ley orgánica constitucional antes mencionada, motivo por el cual no corresponde pronunciarse sobre éste;

DECIMOPRIMERO. Que el artículo 19, $\mathrm{N}^{\circ} 3^{\circ}$, inciso quinto, de la Constitución dispone que "toda sentencia de un órgano que ejerza jurisdicción debe fundarse en un proceso previo legalmente tramitado. Corresponderá al legislador establecer siempre las garantías de un procedimiento y una investigación racionales y justos”;

DECIMOSEGUNDO. Que, como ya tuviera ocasión de señalarlo esta Magistratura en sentencia de 21 de diciembre de 1987, dictada en los autos Rol $\mathrm{N}^{\circ} 46$, "todo juzgamiento debe emanar de un órgano objetivamente independiente y subjetivamente imparcial, elementos esenciales del debido proceso que consagra toda la doctrina procesal contemporánea”. "Es más, a juicio de este Tribunal, la independencia 
e imparcialidad del juez no sólo son componentes de todo proceso justo y racional, sino, además, son elementos consustanciales al concepto mismo de tal." (Considerando décimo);

DECIMOTERCERO. Que el artículo $5^{\circ}$ del artículo primero del proyecto remitido dispone que los Jueces y Secretarios Abogados de los Tribunales Tributarios y Aduaneros serán nombrados por el Presidente de la República de una terna propuesta por la Corte de Apelaciones respectiva;

DECIMOCUARTO. Que, de acuerdo con la misma disposición, ésta será elaborada por la Corte que corresponda a partir "de una lista de un mínimo de cinco y un máximo de diez nombres, que le será propuesta por el Consejo de Alta Dirección Pública con sujeción al procedimiento establecido para el nombramiento de altos directivos públicos...". Se agrega que "el perfil profesional de competencias y aptitudes del cargo... será definido por el Consejo”;

DECIMOQUINTO. Que en el inciso tercero del artículo $5^{\circ}$ se establece que "la Corte de Apelaciones respectiva podrá rechazar, en forma fundada y por una sola vez, todos o algunos de los nombres contenidos en la lista que se le presente";

DECIMOSEXTO. Que en principio no es objetable la participación del Consejo de Alta Dirección Pública en el procedimiento para designar los Jueces y Secretarios Abogados de los nuevos tribunales que se crean por el proyecto en análisis;

DECIMOSEPTIMO. Que, sin embargo, como se ha indicado, el inciso tercero del artículo $5^{\circ}$ señala que las Cortes de Apelaciones podrán objetar total o parcialmente "en forma fundada” y "por una sola vez" la lista confeccionada por el Consejo de Alta Dirección Pública de acuerdo con un perfil profesional de los cargos definido por el mismo. Ello deja entregada la determinación de los candidatos a jueces y secretarios de los Tribunales Tributarios y Aduaneros a dicho órgano, puesto que, agotada la facultad de rechazar todos o algunos de los nombres que se les presenten, las Cortes se verán obligadas a aceptar las propuestas que aquél haga, las cuales, en consecuencia, prevalecerán, limitando seriamente la intervención de los tribunales en el procedimiento que se analiza;

DECIMOCTAVO. Que el entregarle una atribución de tal trascendencia al Consejo de Alta Dirección Pública no se aviene con el carácter de un órgano que forma parte de la Dirección Nacional del Servicio Civil, servicio público descentralizado que integra la Administración del Estado, en términos que den garantía a las partes intervinientes en los asuntos sometidos al conocimiento de los tribunales antes mencionados, de que éstos van a contar, al ejercer sus potestades, con la independencia e imparcialidad que aseguren el derecho al debido proceso contemplado en el artículo $19, \mathrm{~N}^{\circ} 3^{\circ}$, inciso quinto, de la Constitución; 
DECIMONOVENO. Que, por su naturaleza, la potestad propositiva en esta materia resulta propia de los tribunales de justicia, como es el caso de las Cortes de Apelaciones, lo que reconoce por lo demás el mismo artículo $5^{\circ}$, al encomendarles a ellas la confección de las ternas a partir de las cuales el Presidente de la República debe hacer las designaciones correspondientes.

Por la función que desempeñan, las Cortes están en situación de apreciar adecuadamente si los postulantes reúnen las condiciones necesarias para integrar un tribunal que ha de ser "objetivamente independiente" y "subjetivamente imparcial" en el ejercicio de sus facultades jurisdiccionales, en conformidad con las exigencias de un debido proceso;

VIGESIMO. Que, atendido lo que se termina de expresar, la oración “, en forma fundada y por una sola vez," contenida en el inciso tercero del artículo $5^{\circ}$ del artículo primero del proyecto, es contraria a la Carta Fundamental y debe eliminarse de su texto;

VIGESIMOPRIMERO. Que el artículo 284 del Código Orgánico de Tribunales, en su inciso primero, letras a) y b), señala:

"Para proveer los demás cargos del Escalafón Primario, se formarán ternas del modo siguiente:

a) Para ministros y fiscales judiciales de Corte de Apelaciones y secretario de la Corte Suprema, con el juez de tribunal de juicio oral en lo penal, el juez de letras o el juez de juzgado de garantía más antiguo de asiento de Corte calificado en lista de méritos y que exprese su interés por el cargo y con dos ministros de Corte de Apelaciones o integrantes de la segunda o tercera categoría que se hayan opuesto al concurso, elegidos de conformidad a lo establecido en el inciso primero del artículo 281;

b) Para integrantes de las categorías tercera y cuarta, con excepción de los relatores de las Cortes de Apelaciones, con el juez de tribunal de juicio oral en lo penal, el juez de letras o el juez de juzgado de garantía más antiguo de la categoría inferior calificado en lista de méritos y que exprese su interés en el cargo y con dos integrantes de la misma categoría del cargo que se trata de proveer o de la inmediatamente inferior, que se hayan opuesto al concurso, elegidos de conformidad a lo establecido en el inciso primero del artículo 281.”;

VIGESIMOSEGUNDO. Que en el $\mathrm{N}^{\circ}$ 6) del artículo sexto del proyecto se modifican las letras a) y b) de dicho precepto intercalando, "a continuación de la expresión "juez de letras”, la frase “, el juez tributario y aduanero";

VIGESIMOTERCERO. Que dicha reforma tiene por objeto permitir que los jueces tributarios y aduaneros formen, por derecho propio, en caso de tener la antigüedad que establecen las normas que se trata de modificar y cumplir las demás exigencias que ellas señalan, las ternas para proveer los cargos del Escalafón Primario del Poder Judicial comprendidos en las letras a) y b) del mencionado artículo 284 del cuerpo legal antes indicado; 
VIGESIMOCUARTO. Que la Corte Suprema, al referirse a la modificación contenida en el $\mathrm{N}^{\circ}$ 6) del artículo sexto del proyecto en su oficio $\mathrm{N}^{\circ} 349$ de 2 de noviembre de 2007, se pronunció adversamente, indicando que "posibilitará que funcionarios extraños a la carrera judicial y cuyas funciones se limitan a asuntos tributarios y aduaneros, postulen a cargos de Ministros de Cortes de Apelaciones, Relatores y Secretario de la Corte Suprema, Jueces de Asiento de Corte, Relatores y Secretarios de Cortes de Apelaciones y Jueces de capital de provincia...desplazando infundadamente a los titulares de las categorías inferiores del Escalafón, con menoscabo de su legítimo derecho a progresar en su carrera.";

VIGESIMOQUINTO. Que en el artículo $1^{\circ}$ del artículo primero del proyecto en análisis se indica que "los Tribunales Tributarios y Aduaneros son órganos jurisdiccionales letrados, especiales e independientes en el ejercicio de su ministerio...”;

VIGESIMOSEXTO. Que de esa disposición y de las demás que configuran su estructura, organización y funcionamiento se desprende que se está en presencia de tribunales especiales que no integran el Poder Judicial. De este modo, los jueces de dichos órganos jurisdiccionales no forman parte de ese Poder del Estado;

VIGESIMOSEPTIMO. Que, al respecto, en el informe de la Comisión de Constitución, Legislación, Justicia y Reglamento del Senado, de fecha 8 de julio de 2008, recaído en el proyecto, se indica "que primó la tesis de no integrar los Tribunales Tributarios y Aduaneros al Poder Judicial y de instaurarlos como una judicatura especializada, de aquellas a que se refiere el inciso cuarto del artículo $5^{\circ}$ del Código Orgánico de Tribunales, sin perder de vista que el artículo 82 de la Constitución Política de la República los deja sujetos a la superintendencia de la Corte Suprema."

Se señala en el mismo sentido en el informe que, ante dicha Comisión, el Director de Impuestos Internos expresó "que se busca instaurar una justicia tributaria y aduanera ágil, altamente especializada e independiente de la Administración, que no forme parte del Poder Judicial.”;

VIGESIMOCTAVO. Que el artículo 78 de la Constitución Política, al referirse al nombramiento de los jueces, establece en sus incisos primero al octavo lo siguiente:

"En cuanto al nombramiento de los jueces, la ley se ajustará a los siguientes preceptos generales.

La Corte Suprema se compondrá de veintiún ministros.

Los ministros y los fiscales judiciales de la Corte Suprema serán nombrados por el Presidente de la República, eligiéndolos de una nómina de cinco personas que, en cada caso, propondrá la misma Corte, y con acuerdo del Senado. Este adoptará los respectivos acuerdos por los dos tercios de sus miembros en ejercicio, en sesión especialmente convocada al efecto. Si el Senado no aprobare la proposición del Presidente de la República, la Corte Suprema deberá completar la quina proponiendo un nuevo nombre en sustitución del rechazado, repitiéndose el procedimiento hasta que se apruebe un nombramiento. 
Cinco de los miembros de la Corte Suprema deberán ser abogados extraños a la administración de justicia, tener a lo menos quince años de título, haberse destacado en la actividad profesional o universitaria y cumplir los demás requisitos que señale la ley orgánica constitucional respectiva.

La Corte Suprema, cuando se trate de proveer un cargo que corresponda a un miembro proveniente del Poder Judicial, formará la nómina exclusivamente con integrantes de éste y deberá ocupar un lugar en ella el ministro más antiguo de Corte de Apelaciones que figure en lista de méritos. Los otros cuatro lugares se llenarán en atención a los merecimientos de los candidatos. Tratándose de proveer una vacante correspondiente a abogados extraños a la administración de justicia, la nómina se formará exclusivamente, previo concurso público de antecedentes, con abogados que cumplan los requisitos señalados en el inciso cuarto.

Los ministros y fiscales judiciales de las Cortes de Apelaciones serán designados por el Presidente de la República, a propuesta en terna de la Corte Suprema.

Los jueces letrados serán designados por el Presidente de la República, a propuesta en terna de la Corte de Apelaciones de la jurisdicción respectiva.

El juez letrado en lo civil o criminal más antiguo de asiento de Corte o el juez letrado civil o criminal más antiguo del cargo inmediatamente inferior al que se trata de proveer y que figure en lista de méritos y exprese su interés en el cargo, ocupará un lugar en la terna correspondiente. Los otros dos lugares se llenarán en atención al mérito de los candidatos.";

VIGESIMONOVENO. Que las normas transcritas en el considerando anterior permiten que personas extrañas al Poder Judicial puedan formar parte de las nóminas que se elaboren para integrar la Corte Suprema en la forma y de acuerdo con lo que en ellas se indica, pero no así para proveer los cargos a que alude el artículo 284 , letras a) y b), del Código Orgánico de Tribunales. Para que esto último procediere, la Carta Fundamental habría tenido que señalarlo expresamente, lo cual, como puede apreciarse, no ocurre;

TRIGESIMO. Que en forma similar se pronunció esta Magistratura en sentencia de 25 de abril de 1995, dictada en los autos Rol $\mathrm{N}^{\circ} 197$, refiriéndose a las normas constitucionales sobre la misma materia entonces vigentes, las cuales, en cuanto al asunto en examen, no sufrieron alteraciones con ocasión de la dictación de la Ley de Reforma Constitucional $\mathrm{N}^{\circ}$ 19.541, de 22 de diciembre de 1997;

TRIGESIMOPRIMERO. Que, en esa oportunidad, se indicó en el mismo sentido lo siguiente:

"Que...cabe señalar que del texto de las Actas de las Sesiones Nos. 255, 256 y 331, de 2 y 4 de noviembre de 1976 y 7 de diciembre de 1977, respectivamente, de la Comisión de Estudio de la Nueva Constitución Política de la República, es posible concluir que por parte de algunos comisionados se propuso permitir el ingreso a los cargos de ministros y fiscales de Corte de Apelaciones a personas extrañas a la Administración 
de Justicia, lo que, luego de escucharse las opiniones del Presidente de la Corte Suprema y del Ministro de Justicia, fue rechazado por la propia Comisión, considerándose que ello sólo era admisible respecto de la Corte Suprema, por la naturaleza misma de sus funciones, y por cuanto se consideró también que la carrera judicial propiamente tal debía terminar a nivel de miembro de Corte de Apelaciones";

TRIGESIMOSEGUNDO. Que, por las consideraciones anteriores, las modificaciones que se introducen a las letras a) y b) del artículo 284 del Código Orgánico de Tribunales por el $\mathrm{N}^{\circ}$ 6) del artículo sexto del proyecto, al disponer que jueces tributarios y aduaneros que no forman parte del Poder Judicial, en caso de tener la antigüedad respectiva y cumplir los demás requisitos exigidos, integren por derecho propio las ternas a que aluden los preceptos que se pretenden reformar, son contrarias a lo dispuesto en el inciso octavo de la Constitución Política y deben eliminarse de su texto;

TRIGESIMOTERCERO. Que el artículo $1^{\circ}$ del artículo primero del proyecto en estudio establece las funciones de los Tribunales Tributarios y Aduaneros. En su $\mathrm{N}^{\circ} 8^{\circ}$ dispone que les corresponde "conocer de las demás materias que señale la ley";

TRIGESIMOCUARTO. Que, de igual forma, el nuevo artículo 117, contenido en el Título VI del Libro II de la Ordenanza de Aduanas, reemplazado por el No 5) del artículo tercero del proyecto en examen, señala que serán de competencia de los tribunales antes mencionados "las reclamaciones en contra de las siguientes actuaciones del Servicio Nacional de Aduanas: d) Las demás que establezca la ley.”;

TRIGESIMOQUINTO. Que la competencia "de los tribunales que fueren necesarios para la pronta y cumplida administración de justicia en todo el territorio de la República” es materia propia de una ley orgánica constitucional en conformidad con lo que dispone el artículo 77, inciso primero, de la Ley Suprema;

TRIGESIMOSEXTO. Que, en consecuencia, las referencias que el artículo $1^{\circ}$ del artículo primero en su $\mathrm{N}^{\circ} 8$ ) y el artículo 117 , letra d), contenido en el $\mathrm{N}^{\circ}$ 5) del artículo tercero, ambos del proyecto sujeto a control, hacen a "la ley" deben entenderse que lo son a un cuerpo legal de naturaleza orgánica constitucional;

TRIGESIMOSEPTIMO. Que el artículo $9^{\circ}$ del artículo primero del proyecto remitido señala que "los Jueces Tributarios y Aduaneros podrán perder su competencia para conocer determinados negocios por implicancia o recusación declaradas, en virtud de las causales contempladas en los artículos 195 y 196 del Código Orgánico de Tribunales.";

TRIGESIMOCTAVO. Que al indicar la disposición que los jueces a que alude "podrán perder su competencia” al estar afectados por una causal de implicancia o recusación, dicha expresión debe entenderse en el sentido de que éstos quedan inhabilitados para 
participar en el conocimiento del asunto respectivo, puesto que el Tribunal Tributario y Aduanero del cual forman parte no pierde su competencia respecto de las materias que le conciernen al concurrir una causal de inhabilidad en relación con un juez;

TRIGESIMONOVENO. Que el artículo 14 del artículo primero del proyecto en examen dispone:

"Son funciones de los Secretarios Abogados:

$1^{\circ}$. Subrogar al Juez Tributario y Aduanero en los términos expresados en el artículo 10;

$2^{\circ}$. Asesorar al Juez Tributario y Aduanero en el ejercicio de su ministerio;

$3^{\circ}$. Velar por la realización de las notificaciones en la forma que señala la ley y por que se deje testimonio de ellas en el expediente. Para la ejecución de estas tareas podrá designar a uno o más abogados resolutores o profesionales expertos, y

$4^{\circ}$. Ejercer las demás tareas que le sean asignadas por el Juez Tributario y Aduanero."

CUADRAGESIMO. Que en relación con el $\mathrm{N}^{\circ} 2^{\circ}$ del artículo 14 del artículo primero del proyecto en estudio, dicha disposición es constitucional en el entendido que, en ejercicio de la atribución a que se refiere, los Secretarios Abogados deben colaborar y prestar consejo al Juez cuando éste lo requiera, pero, en ningún caso, pueden, en dicha calidad, ejercer jurisdicción, la que es privativa de los Jueces que constituyen los Tribunales Tributarios y Aduaneros en conformidad con lo que dispone el artículo $3^{\circ}$ del artículo primero del proyecto;

CUADRAGESIMOPRIMERO. Que respecto al No $4^{\circ}$ del artículo 14 del artículo primero del proyecto en examen, que autoriza a los Secretarios Abogados para ejecutar las demás tareas que se les asigne por el Tribunal, la norma es constitucional en el entendido que ellas han de guardar relación con la naturaleza del cargo que éstos desempeñan, como lo es el servir de ministros de fe, sin perjuicio de lo que el artículo $15, \mathrm{~N}^{\circ} 2^{\circ}$, del artículo primero dispone para casos específicos;

CUADRAGESIMOSEGUNDO. Que el artículo 16 del artículo primero del proyecto remitido indica:

"Los funcionarios del Tribunal Tributario y Aduanero tendrán prohibición de ejercer libremente su profesión u otra actividad remunerada, y de ocupar cargos directivos, ejecutivos y administrativos en otras entidades, sea que persigan o no fines de lucro.

No obstante lo dispuesto en el inciso anterior, el desempeño como funcionario del Tribunal Tributario y Aduanero será compatible con los cargos docentes, hasta un máximo de seis horas semanales.";

CUADRAGESIMOTERCERO. Que, en relación con la prohibición contenida en la disposición "de ejercer...otra actividad remunerada", debe entenderse que ella está de acuerdo con la Carta Fundamental en cuanto se refiere al ejercicio de una actividad 
laboral por la cual se obtiene una retribución, sin quedar comprendida en ella la administración del propio patrimonio que el Juez Tributario y Aduanero posea, lo que, como resulta evidente, en nada afecta al principio de independencia de los tribunales de justicia consagrado en la Constitución;

CUADRAGESIMOCUARTO. Que respecto a la prohibición "de ocupar cargos directivos, ejecutivos y administrativos en otras entidades, sea que persigan o no fines de lucro”, ella no vulnera la Constitución Política si se tiene presente que está regulando la libertad de trabajo de los nuevos jueces con el razonable propósito de evitar los conflictos de intereses que, como consecuencia de las funciones que están llamados a desempeñar, se les pueden presentar;

CUADRAGESIMOQUINTO. Que el No 44) del artículo segundo del proyecto remitido introduce al Código Tributario el artículo 155, que señala:

"Si producto de un acto u omisión del Servicio, un particular considera vulnerados sus derechos contemplados en los numerales $21^{\circ}, 22^{\circ}$ y $24^{\circ}$ del artículo 19 de la Constitución Política de la República, podrá recurrir ante el Tribunal Tributario y Aduanero en cuya jurisdicción se haya producido tal acto u omisión, siempre que no se trate de aquellas materias que deban ser conocidas en conformidad a alguno de los procedimientos establecidos en el Título II o en los Párrafos $1^{\circ}$ y $3^{\circ}$ de este Título o en el Título IV, todos del Libro Tercero de este Código.

La acción deberá presentarse por escrito, dentro del plazo fatal de quince días hábiles contado desde la ejecución del acto o la ocurrencia de la omisión, o desde que se haya tenido conocimiento cierto de los mismos, lo que se hará constar en autos.

Interpuesta la acción de protección a que se refiere el artículo 20 de la Constitución Política, en los casos en que ella proceda, no se podrá recurrir de conformidad a las normas de este Párrafo, por los mismos hechos.";

CUADRAGESIMOSEXTO. Que, a su vez, el $N^{\circ}$ 5) del artículo tercero del proyecto en estudio incorpora a la Ordenanza de Aduanas el artículo $129 \mathrm{~K}$, que establece:

"Si producto de un acto u omisión del Servicio, un particular considerare vulnerados sus derechos contemplados en los numerales $21^{\circ}, 22^{\circ}$ y $24^{\circ}$ del artículo 19 de la Constitución Política de la República, podrá recurrir ante el Tribunal Tributario y Aduanero en cuya jurisdicción se hubiere producido tal acto u omisión, siempre que no se trate de materias cuyo conocimiento la ley somete a un procedimiento distinto ante estos tribunales.

La acción deberá presentarse por escrito dentro del plazo fatal de quince días hábiles contado desde la ejecución del acto o la ocurrencia de la omisión, o desde que se haya tenido conocimiento cierto de los mismos, lo que se hará constar en autos.

Interpuesta la acción de protección a que se refiere el artículo 20 de la Constitución Política, en los casos en que ella proceda, no se podrá recurrir de conformidad a las normas de este Párrafo, por los mismos hechos." 
CUADRAGESIMOSEPTIMO. Que, como se advierte, el inciso tercero de ambas normas señala que "interpuesta" una acción de protección "no se podrá" deducir la acción de amparo de derechos constitucionales que en ellas se consagra.

CUADRAGESIMOCTAVO. Que dichos preceptos están de acuerdo con la Constitución en cuanto la palabra "interpuesta" se entiende como "declarada admisible" la acción de protección presentada por parte de la Corte de Apelaciones respectiva, porque en caso contrario el o los afectados quedarían privados tanto de la acción de protección contemplada en el artículo 20 de la Constitución Política como de aquellas que se consagran en los nuevos artículos 155 del Código Tributario y 129 $\mathrm{K}$ de la Ordenanza de Aduanas, lo que contravendría lo dispuesto en los artículos 19, $\mathrm{N}^{\mathrm{o}} 3^{\circ}$, y 76 de la Carta Fundamental, que consagran el derecho a la acción como forma de iniciar un proceso;

CUADRAGESIMONOVENO. Que el artículo 199 de la Ordenanza de Aduanas establece, en su inciso final, lo siguiente:

"El Agente de Aduana se subrogará legalmente en los derechos privilegiados del Fisco cuando, por cuenta del mandante, hubiere pagado sumas de dinero por concepto de gravámenes, de cualquiera clase y diferencias de tributos, como consecuencia de cargos emitidos por la Aduana. La subrogación alcanzará al capital e intereses corrientes hasta el momento del pago por parte del mandante. Copia autorizada por la Aduana del documento de pago que deberá mencionar el nombre del deudor, servirá al Agente de Aduana de título ejecutivo para accionar en contra de éste para el reembolso de las sumas pagadas por su cuenta, en conformidad al Libro III del Código de Procedimiento Civil. El mismo procedimiento ejecutivo tendrá lugar cuando el Agente de Aduana haya pagado multas por infracciones que no deban ser soportadas en definitiva por él, según lo resuelva, a petición de cualquiera de las partes y previa audiencia de ambas, la Junta General de Aduanas.";

QUINCUAGESIMO. Que en el No 12) del artículo tercero del proyecto se modifica la última parte de dicho precepto indicándose que, tratándose de las multas que el Agente de Aduana haya pagado por infracciones por las cuales no le corresponda responder, podrá accionar, a través del procedimiento ejecutivo, en contra del deudor, según lo que resuelva al respecto "sin forma de juicio y escuchando a las partes, el Tribunal Tributario y Aduanero respectivo.";

QUINCUAGESIMOPRIMERO. Que dicha reforma es constitucional en el entendido de que el procedimiento al cual se debe ceñir este proceso a través del cual el Tribunal Tributario y Aduanero que corresponda ha de resolver si la multa es de cargo del mandante o del Agente de Aduana, debe estar establecido con anterioridad, ha de ser conocido de las partes y es necesario que cumpla con los requisitos de racionalidad y justicia exigidos por el artículo $19, \mathrm{~N}^{\circ} 3^{\circ}$, inciso quinto, de la Carta Fundamental; 
QUINCUAGESIMOSEGUNDO. Que consta de autos que los preceptos indicados en los considerandos sexto y noveno de esta sentencia han sido aprobados en ambas Cámaras del Congreso Nacional con las mayorías requeridas por el inciso segundo del artículo 66 de la Constitución Política de la República, y que sobre ellos no se ha suscitado cuestión de constitucionalidad;

QUINCUAGESIMOTERCERO. Que, igualmente, consta de los antecedentes que se ha dado cumplimiento a lo dispuesto en el artículo 77, inciso segundo, de la Carta Fundamental;

QUINCUAGESIMOCUARTO. Que las disposiciones a que se ha hecho referencia en el considerando quincuagesimosegundo, con excepción de la frase “,en forma fundada y por una sola vez," comprendida en el inciso tercero del artículo $5^{\circ}$ del artículo primero, y de la norma contenida en el $\mathrm{N}^{\circ}$ 6) del artículo sexto, ambos del proyecto remitido, no son contrarias a la Carta Fundamental.

Y VISTO lo dispuesto en los artículos $6^{\circ}, 19, \mathrm{~N}^{\circ} 3^{\circ}, 20,66$, inciso segundo, 76, 77 , incisos primero y segundo, 78, 93, inciso primero, $\mathrm{N}^{\circ} 1^{\circ}$, e inciso segundo, de la Constitución Política de la República y lo prescrito en los artículos 34 al 37 de la Ley $\mathrm{N}^{\circ}$ 17.997, de 19 de mayo de 1981, Orgánica Constitucional de este Tribunal,

\section{SE DECLARA:}

$1^{\circ}$. Que la frase “, en forma fundada y por una sola vez,", contenida en el inciso tercero del artículo $5^{\circ}$ del artículo primero del proyecto remitido, es inconstitucional y debe eliminarse de su texto.

$2^{\circ}$. Que las modificaciones introducidas a las letras a) y b) del artículo 284 del Código Orgánico de Tribunales por el $\mathrm{N}^{\circ}$ 6) del artículo sexto del proyecto remitido son inconstitucionales y deben eliminarse de su texto.

$3^{\circ}$. Que las disposiciones contenidas en los artículos $1^{\circ}, 3^{\circ}, 4^{\circ}$, inciso primero, $5^{\circ}-$ con excepción de la oración ", en forma fundada y por una sola vez," comprendida en su inciso tercero- $, 6^{\circ}, 7^{\circ}, 8^{\circ}, 9^{\circ}, 10,11,12,14$ y 16 en lo relativo a los jueces, del artículo primero; en los números 7), 8), 11), 14), 15), 16), 31), 32), 39), 41), 44) respecto del inciso primero del artículo 155,48 ), letras a) y g), 49), letras b), c) y d), y 50), letras c) y g), del artículo segundo; en los números 2), 3), 5) en relación con los artículos 117, 118, 119, 129 D y $129 \mathrm{~K}$, incisos primero y tercero, 8), letra a), 12) y 13), letra a), del artículo tercero; en los números 1), letra a), 2), 3) y 4), del artículo quinto; en el artículo sexto -con excepción de aquella contemplada en su $\mathrm{N}^{\circ}$ 6) - y en el artículo $8^{\circ}$ permanentes, y en los artículos primero, segundo, tercero, cuarto, quinto y décimo transitorios del proyecto remitido, sin perjuicio de lo que se indica en los numerales $4^{\circ}$ a 10 de esta sentencia, son constitucionales.

$4^{\circ}$. Que los artículos $1^{\circ}, \mathrm{N}^{\circ} 8$ ), del artículo primero, y 117 , letra d), que el artículo tercero, $\mathrm{N}^{\circ}$ 5), del proyecto remitido incorpora a la Ordenanza de Aduanas son 
constitucionales en el entendido de que la referencia a "la ley" que en ellos se hace lo es a una ley orgánica constitucional.

$5^{\circ}$. Que la disposición contenida en el artículo $9^{\circ}$ del artículo primero del proyecto remitido, en cuanto señala que "Los Jueces Tributarios y Aduaneros podrán perder su competencia para conocer determinados negocios por implicancia o recusación declaradas, en virtud de las causales contempladas en los artículos 195 y 196 del Código Orgánico de Tribunales”, es constitucional en el entendido que éstos quedan inhabilitados para participar en el conocimiento del asunto respectivo.

$6^{\circ}$. Que la disposición contenida en el artículo $14, \mathrm{~N}^{\circ} 2^{\circ}$, del artículo primero del proyecto remitido es constitucional en el entendido de que en ejercicio de la atribución a que se refiere, los Secretarios Abogados deben colaborar y prestar consejo al Juez cuando éste lo requiera, pero, en ningún caso, pueden, en dicha calidad, ejercer jurisdicción, la que es privativa de los Jueces que constituyen los Tribunales Tributarios y Aduaneros.

$7^{\circ}$. Que la disposición contenida en el artículo $14, \mathrm{~N}^{\circ} 4^{\circ}$, del artículo primero del proyecto remitido es constitucional en el entendido de que las tareas que le sean asignadas a los Secretarios Abogados han de guardar relación con la naturaleza del cargo que éstos desempeñan, como lo es el servir de ministros de fe, sin perjuicio de lo que el artículo $15, \mathrm{~N}^{\circ} 2^{\circ}$, del artículo primero dispone para casos específicos.

$8^{\circ}$. Que la disposición contenida en el artículo 16 del artículo primero del proyecto remitido, en cuanto prohíbe ejercer "otra actividad remunerada", es constitucional en el entendido que se refiere al ejercicio de una actividad laboral por la cual se obtiene una retribución, sin quedar comprendida en ella la administración del propio patrimonio que el Juez Tributario y Aduanero posea.

$9^{\circ}$. Que la palabra “interpuesta” contenida en el artículo 155, inciso tercero, que el $\mathrm{N}^{\circ}$ 44) del artículo segundo introduce al Código Tributario y en el artículo 129 $\mathrm{K}$, inciso tercero, que el $\mathrm{N}^{\circ}$ 5) del artículo tercero incorpora a la Ordenanza de Aduanas, ambos del proyecto remitido, es constitucional en el sentido de que la improcedencia de las acciones a que dichos preceptos se refieren solo tiene lugar desde que la Corte de Apelaciones respectiva declara admisible el recurso de protección deducido.

$10^{\circ}$. Que la disposición contenida en el $\mathrm{N}^{\mathrm{o}} 12$ ) del artículo tercero del proyecto remitido, que modifica el artículo 199, inciso final, de la Ordenanza de Aduanas, es constitucional en el entendido de lo que se indica en el considerando quincuagesimoprimero de esta sentencia. El procedimiento al cual se debe ceñir el proceso a través del cual el Tribunal Tributario y Aduanero que corresponda ha de resolver si la multa es de cargo del mandante o del Agente de Aduana, debe cumplir con los presupuestos de racionalidad y justicia exigidos por el artículo $19, \mathrm{~N}^{\circ} 3^{\circ}$, inciso quinto, de la Carta Fundamental.

$11^{\circ}$. Que el inciso tercero del artículo 155 que el $\left.\mathrm{N}^{\circ} 44\right)$ del artículo segundo del proyecto remitido incorpora al Código Tributario es, también, constitucional. 
$12^{\circ}$. Que no le corresponde a este Tribunal pronunciarse sobre las disposiciones contenidas en los artículos $4^{\circ}$, inciso final, 17 y 25 del artículo primero; en el número 5) respecto al artículo $129 \mathrm{~K}$, inciso segundo, del artículo tercero, y en el artículo $9^{\circ}$ transitorio, letra b), del proyecto remitido, por no versar sobre materias propias de ley orgánica constitucional.

$13^{\circ}$. Que tampoco lo corresponde a este Tribunal pronunciarse sobre el inciso segundo del artículo 155 que el $\mathrm{N}^{\circ} 44$ ) del artículo segundo del proyecto remitido incorpora al Código Tributario, por no versar sobre una materia propia de ley orgánica constitucional.

Se previene que el Ministro señor Raúl Bertelsen Repetto estuvo por no hacer los entendidos contenidos en los numerales $5^{\circ}, 6,7^{\circ}$ y $8^{\circ}$ de la parte resolutiva por estimarlos innecesarios, pues a su juicio, las disposiciones a que aluden no admiten otra inteligencia.

Se previene que el Ministro señor Jorge Correa Sutil estuvo por no hacer el entendido contenido en el numeral $8^{\circ}$ de la parte resolutiva, por la misma razón indicada en la prevención anterior.

Se previene que el Ministro señor Enrique Navarro Beltrán concurre al fallo teniendo presente, en relación al artículo $5^{\circ}$ del artículo primero del proyecto, adicionalmente lo siguiente:

PRIMERO. Que el artículo en referencia señala que el Juez Tributario y Aduanero será nombrado por el Presidente de la República, de una terna elaborada por la respectiva Corte de Apelaciones, la que a su vez será confeccionada sobre la base de una lista de un mínimo de cinco y un máximo de diez nombres propuesta por el Consejo de la Alta Dirección Pública;

SEGUNDO. Que de la historia fidedigna del establecimiento de la norma se desprende que no se trató de una materia en la que existiera consenso por parte de los colegisladores. La norma sufrió modificaciones desde el texto primitivo, en que se entregaba al Ministerio de Hacienda dicha facultad, hasta el definitivo, en el que se la radicó en el Consejo de la Alta Dirección Pública, con el propósito específico de garantizar la "idoneidad de los jueces tributarios". Ello motivó que algunos parlamentarios hicieran presente eventuales dudas sobre la constitucionalidad del texto (Senador Vásquez, entre otros). A su turno, ciertos diputados insistieron en la idea de que la Corte de Apelaciones debía elaborar con absoluta libertad las ternas con los candidatos que cumplieran con las debidas exigencias de especialización tributaria. Incluso se sostuvo que el concurso podría estar única e íntegramente en manos del Poder Judicial (Senador Gómez). Por lo mismo, la Corte Suprema hizo presente sus reparos en cuanto a la intervención de órganos que se relacionan con el Ejecutivo a través del Ministerio de Hacienda, de forma tal que "sería preferible entregar a las mismas Cortes de Apelaciones la ejecución de tales concursos públicos" (Oficios 349, de 2 de noviembre de 2007, y 176, de 6 de diciembre de 2005); 
TERCERO. Que este tipo de procedimientos de designación de jueces, que podría denominarse de carácter mixto, no es del todo ajeno al ordenamiento jurídico chileno, aunque excepcional, si se piensa que, por ejemplo, tratándose del Tribunal de Defensa de la Libre Competencia, de conformidad a la Ley $\mathrm{N}^{\circ} 19.911$, participan órganos ajenos al Poder Judicial, como es el Banco Central, situación que fue estimada como ajustada a la Constitución Política por parte de esta Magistratura (Rol No 391/2003). Algo similar -aunque evidentemente con matices- podría sostenerse respecto del Tribunal de la Contratación Pública (Rol No 378/2003) y del Tribunal de Propiedad Industrial (Rol No 432/2005). De hecho, la Constitución Política autoriza incluso que órganos de la Administración ejerzan jurisdicción, aunque sujeto a los principios de todo debido proceso, en los términos que señala el artículo $19 \mathrm{~N}^{\circ} 3$ de la Carta Fundamental, como lo indicaron, en su momento, la Corte Suprema y, desde el 2006, esta Magistratura. Así, aunque se trata de una situación de mérito, que debe evaluar el legislador, se ha empleado especificamente en órganos que no forman parte del Poder Judicial, aunque sí sujetos a la superintendencia de la Corte Suprema. En este caso, incluso, los jueces tributarios y aduaneros serán calificados anualmente por la respectiva Corte de Apelaciones. Resulta, en todo caso, extraño el empleo de un mecanismo como el de la Alta Dirección Pública, que es más bien propio de organismos de carácter administrativo, en los términos que establece la Ley $\mathrm{N}^{\circ} 19.882$, no debiendo olvidarse que la judicatura se estructura sobre la base de oficios y no de oficinas, a lo que debe agregarse la circunstancia que de acuerdo a recientes instrucciones dictadas por la Corte Suprema toda designación de jueces y funcionarios judiciales debe efectuarse sobre la base de un concurso público, en estricta armonía por lo demás con lo dispuesto en el artículo $8^{\circ}$ de la Constitución Política;

CUARTO. Que no puede desconocerse la circunstancia de que el proyecto en cuestión importa un avance significativo en la justicia tributaria chilena. En efecto, por más de medio siglo las reclamaciones tributarias han sido de competencia de los Directores Regionales del Servicio de Impuestos Internos, en cuanto órganos que ejercen jurisdicción y que no forman parte del Poder Judicial. Ello motivó abundante crítica por parte de la doctrina especializada nacional (Vid., entre otros, Revista de Derecho Económico, N 64, Facultad de Derecho de la Universidad de Chile, 1984, y Revista de Derecho de la Universidad Finis Terrae, $\mathrm{N}^{\circ}$ 4, 2000) e, incluso, extranjera (Ramón Valdés Costa, Estudios de Derecho Tributario Latinoamericanos, Montevideo, 1982);

QUINTO. Que esta misma Magistratura ya había señalado que el Director Regional del Servicio de Impuestos, como órgano jurisdiccional de primera instancia, no se encontraba sujeto a las instrucciones que pudiere emitir al efecto el propio Servicio, debiendo fallar de acuerdo al mérito del proceso, a la prueba rendida, y respetando siempre los principios de un debido proceso (Rol No 616/2007). Lo sustancial es que, a partir de ahora, se trata de una judicatura letrada, especializada e independiente de la autoridad administrativa; 
SEXTO. Que esta independencia podría verse -eventualmente- afectada por la existencia de una Unidad Administradora, establecida en los artículos 18 y siguientes del proyecto. Se trata de un órgano funcionalmente desconcentrado de la Subsecretaría de Hacienda a quien se le otorgan ciertas facultades de gestión administrativa, tales como el pago de remuneraciones, provisión de inmuebles, adquisición de materiales y medios informáticos y, en general, la ejecución de la administración financiera de los tribunales. Su vinculación tiene pues sólo carácter administrativo, toda vez que siempre su dependencia jerárquica y jurisdiccional quedará sujeta a la respectiva Corte de Apelaciones y, en definitiva, a la Corte Suprema, cuyas facultades tienen fundamento constitucional, según lo ha señalado esta Magistratura (Rol No 795/2007). Al aprobarse esta norma un Senador señaló que el establecimiento de dicha repartición "rompe el necesario principio de independencia judicial" (señor Larraín). Otros propusieron que formara parte de la Corporación Administrativa del Poder Judicial (Novoa y Prokurica). Ello motivó que la Corte Suprema hiciera presente que los Tribunales Tributarios y Aduaneros, al depender de dicha unidad, no sería "posible reconocerle(s) la autonomía propia del ejercicio de la jurisdicción a cargo de tribunales independientes de otros Poderes del Estado, en especial si por la naturaleza de los asuntos comprendidos en su competencia, deberá conocer de reclamaciones en contra de actuaciones de otros Servicios que se relacionan precisamente con la misma Subsecretaría de Hacienda" (Oficio 349, de 2 de noviembre de 2007). En todo caso, según de dejó constancia expresamente en la discusión de la disposición, el Ejecutivo se comprometió a revisar esta institución, por lo que su carácter debía ser más bien transitorio, mientras se implementa la nueva legislación;

SEPTIMO. Que esta materia - que puede adquirir especial trascendencia- no ha sido sometida a conocimiento de este Tribunal por el Congreso Nacional y no presenta el carácter de normativa orgánica constitucional, al no referirse a la organización y atribuciones de los tribunales que fueren necesarios para la pronta y cumplida administración de justicia, en los términos que indica el artículo 77 de la Carta Fundamental, tal como se ha resuelto en casos similares por esta Magistratura (por ejemplo, en los autos Roles $\mathrm{N}^{\circ}$ s 107/1990, 304/2000 y 442/2005, entre otros), por lo que no corresponde sea revisada en esta etapa de control preventivo obligatorio. En todo caso, como afirma Stolleis Michael (Geschichte des öffentlichen Rechts in Deutschland), el Estado de Derecho no es barato, pero sin tribunales independientes no existe verdaderamente un Estado de Derecho. Dentro de dicha autonomía por cierto debe encontrarse la financiera. Y es que, como señalara el gran jurista Karl Loewenstein en su clásica obra Teoría de la Constitución, "la independencia de los jueces en el ejercicio de las funciones que les han sido asignadas y su libertad frente a todo tipo de interferencias de cualquier otro detentador del poder, constituye la piedra final en el edificio del Estado Democrático Constitucional de Derecho".

Acordada con el voto en contra de los Ministros señores Hernán Vodanovic Schnake y Mario Fernández Baeza, y del Ministro señor Marcelo Venegas Palacios sólo en lo concerniente a los artículos 16 y 18 a 23, quienes estuvieron por declarar inconstitucional el artículo $5^{\circ}$, inciso segundo; el artículo 12, incisos segundo y tercero; el artículo 16; 
el artículo 18; y los artículos 19 al 23 del artículo primero del proyecto en estudio, por las consideraciones que se indican:

PRIMERO. Que la independencia de los tribunales de justicia, sin perjuicio de la calidad que ostenten, es un principio constitucional, cuya verificación positiva en nuestro ordenamiento jurídico se sitúa en el inciso segundo del artículo $7^{\circ}$ de la Carta y en el inciso primero del artículo 76 del mismo cuerpo normativo. El primero de esos preceptos impide a toda magistratura, persona o grupo de personas atribuirse otra autoridad o derechos que los que expresamente se les hayan conferido por la Constitución o las leyes. El segundo precepto entrega, exclusivamente, a los tribunales establecidos por la ley "la facultad de conocer de las causas civiles y criminales, de resolverlas y de hacer ejecutar lo juzgado";

SEGUNDO. Que el propio proyecto de ley bajo control, en su artículo primero, recoge el citado principio al señalar: "Los Tribunales Tributarios y Aduaneros son órganos jurisdiccionales letrados, especiales e independientes en el ejercicio de su ministerio, cuyas funciones, en el ámbito de su territorio, son:";

TERCERO. Que con la creación de los Tribunales Tributarios y Aduaneros, independientes del Servicio de Impuestos Internos, en cuyos Directores Regionales reside la jurisdicción de primera instancia según el artículo 115 del Código Tributario en vigor, se instaura un primer paso para establecer en Chile una jurisdicción contencioso- administrativa plena;

CUARTO. Que la jurisdicción administrativa es definida, “por distinción con la jurisdicción judicial”, como "un conjunto de jurisdicciones competentes en materia contencioso- administrativa; conjunto de jurisdicciones que garantizan el control jurisdiccional de la administración." (Vocabulario Jurídico de la Asociación Henri Capitant, Temis, Bogotá, 1995, 506). Se entiende, en consecuencia, que requisito de existencia de tal jurisdicción es la independencia completa de la administración, a la que está llamada a controlar jurisdiccionalmente;

QUINTO. Que las normas del proyecto bajo control ya indicadas que, a juicio de estos ministros disidentes, son inconstitucionales, someten, a excepción del artículo 16, a esta nueva magistratura a instituciones o reparticiones externas a ella y a los tribunales establecidos por la ley, en aspectos esenciales de su funcionamiento, dañando severamente su independencia, tanto en relación con los dos preceptos constitucionales descritos en el considerando primero, como también vulnerando los artículos 77, 78, 79, 80 y 82 de la Carta, relativos a la organización y atribuciones de los tribunales, al nombramiento, calificación y destitución de los magistrados, a los deberes que éstos deben cumplir en el ejercicio de sus funciones, y a la facultad de la Corte Suprema relativa a la superintendencia directiva, correccional y económica, que le compete sobre todos los tribunales de la Nación; 
SEXTO. Que dentro de la vulneración constitucional citada cae la atribución, entregada por el inciso segundo del artículo $5^{\circ}$ del proyecto bajo control, al Consejo de Alta Dirección Pública, de proponer a la Corte de Apelaciones respectiva una lista de la cual esta Magistratura de alzada formará la terna para el nombramiento de los Jueces Tributarios y Aduaneros por el Presidente de la República, así como también respecto de los Secretarios Abogados de esta nueva Magistratura;

SEPTIMO. Que el inciso segundo del artículo 12 del proyecto de ley bajo control establece criterios de gestión, término singular éste de tanta actualidad como vaguedad en su contenido, especialmente jurídico, que riñen con los pulcros y precisos deberes de los jueces, establecidos en los artículos 79 y 80 de la Carta Fundamental, y que los convierten en funcionarios equivalentes a los empleados del sector privado, en el cual los criterios de productividad responden a otra lógica, como otra es la naturaleza de su actividad. De especial elocuencia para lo dicho es el requisito señalado en el punto 3 del inciso segundo de este artículo 12 del proyecto: "Tiempos medios de demora de los procesos fallados”. La pregunta que surge de esta norma es: ¿La expresión "buen comportamiento" que el artículo 80 de la Constitución ocupa para describir el requisito para que los jueces permanezcan en sus cargos, se convierte en equivalente de fallar rápido las causas entregadas a su conocimiento? Y si así no fuera, ¿por qué la ley en comento exige incluir ese dato en el informe de gestión?;

OCTAVO. Que el artículo 18, al crear la Unidad Administrativa de los Tribunales Tributarios y Aduaneros, y los artículos 20 y siguientes resultantes de aquél, hacen retroceder todo el proyecto a la dependencia actual de la administración tributaria del Estado y con ello revocan el concepto "independiente" de su artículo primero ya aludido en el considerando segundo de esta disidencia. En efecto, esta Unidad Administradora a la que se asigna "la gestión administrativa de los Tribunales Tributarios y Aduaneros", depende del Ministerio de Hacienda, al igual que el Servicio de Impuestos Internos, repartición a la que la nueva Magistratura está llamada a controlar jurisdiccionalmente. Señala el artículo 18: "Esta Unidad será un órgano funcionalmente desconcentrado de la Subsecretaría de Hacienda, conforme a lo dispuesto en el artículo 33 de la Ley $\mathrm{N}^{0} 18.575 \ldots$..., mismo precepto cuyo inicio deja en claro cuál es el orden de jerarquía que no se excluye por la desconcentración territorial y funcional de determinados órganos: "sin perjuicio de la dependencia jerárquica general”, o sea, el Ministro y el Subsecretario, correspondiéndole a este último, según el artículo 24 de la citada ley: "coordinar la acción de los órganos y servicios públicos del sector, actuar como ministros de fe, ejercer la administración interna del Ministerio y cumplir las demás funciones que les señale la ley”.

Entre los servicios públicos del sector, en este caso de Hacienda, se encuentra el Servicio de Impuestos Internos.

Durante la tramitación de la ley bajo control, hubo reiteradas y críticas alusiones al establecimiento de esta Unidad como reñida con la independencia de la magistratura que se creaba. Así lo expresó el Senador Hernán Larraín durante la aprobación en particular 
del proyecto el 8 de julio de 2008: "Otro punto complicado es el hecho de que se encarga la gestión administrativa a una Unidad que dependerá de la Subsecretaría de Hacienda. El establecimiento de esta repartición rompe el necesario principio de la independencia judicial y obvía la intervención de la Corporación Administrativa del Poder Judicial, que es la institución que tiene a cargo estos temas en el Poder Judicial.”. El Diputado Sr. Álvarez agregó en sesión de la Comisión de Hacienda de la H. Cámara de Diputados del 2 de septiembre: “... el título que crea la Unidad Administrativa es inaceptable, puesto que va a depender de la Subsecretaría de Hacienda y en definitiva será el Fisco, que es parte en estos procesos, quien pagará los sueldos de los funcionarios y del Juez del Tribunal, decidiendo, además, sobre la organización de cursos y conferencias destinados al perfeccionamiento del personal";

NOVENO. Que el artículo 16 establece una prohibición “de ejercer libremente su profesión u otra actividad remunerada, y de ocupar cargos directivos, ejecutivos y administrativos en otras entidades, sea que persigan o no fines de lucro".

De la lectura de dicha norma se desprende que establece una afectación de las libertades de emprendimiento y de trabajo y, en tanto norma específica, establece una desigualdad ante la ley;

DECIMO. Que respecto de la libertad de trabajo y la libertad de empresa, la Constitución establece reservas de ley determinadas, por las cuales el legislador puede regular y afectar el ejercicio de dichos derechos; cabe examinar, entonces, si el precepto aludido se encuentra comprendido en dichas habilitaciones o, por el contrario, está fuera de ellas, de lo cual derivará su constitucionalidad o inconstitucionalidad;

DECIMOPRIMERO. Que, por otra parte, se derive o no su constitucionalidad respecto de las habilitaciones al legislador para regular dichos derechos, al establecer dicha norma un trato diferenciado, el mismo debe cumplir con lo dispuesto en el artículo 19, numeral $2^{\circ}$, de la Constitución, en términos que dicha diferencia no sea de carácter arbitrario;

DECIMOSEGUNDO. Que, en este contexto, la Constitución reconoce en el numeral 16 del artículo 19 la libertad de trabajo, señalando que "Ninguna clase de trabajo puede ser probibida, salvo que se oponga a la moral, a la seguridad o a la salubridad públicas, o que lo exija el interés nacional y una ley lo declare así". Así, el constituyente remite al legislador la regulación del ejercicio del derecho, en una reserva legal específica que reconoce límites en los conceptos transcritos. De la misma forma, el numeral 21 del mismo artículo establece la libertad de empresa, en términos que consagra el "derecho a desarrollar cualquiera actividad económica que no sea contraria a la moral, al orden público o a la seguridad nacional, respetando las normas legales que la regulen";

DECIMOTERCERO. Que, desde luego, no concurren en este caso algunos de los supuestos que permiten prohibir una clase de trabajo -la moral, la seguridad o la 
salubridad públicas- ni la ley invoca o declara una exigencia vinculada al interés nacional para tal efecto;

DECIMOCUARTO. Que la normativa legal que prohíba o limite el ejercicio de estos derechos debe enmarcarse, entre otros, dentro de dos preceptos específicos que limitan la regulación legislativa de todo derecho fundamental: por una parte, la garantía de igualdad ante la ley reconocida en el numeral $2^{\circ}$ del mismo articulo $19 \mathrm{y}$, por otra parte, la garantía del contenido esencial contemplada en su numeral 26 , sin perjuicio de que el numeral 16, en lo tocante a la libertad de trabajo, prohíbe cualquiera discriminación que no se base en la capacidad o idoneidad personal;

DECIMOQUINTO. Que la igualdad ante la ley se traduce, entre otras expresiones, en los caracteres de generalidad y abstracción característicos de este tipo de normas, los cuales suponen que todos los gobernados son destinatarios de ellas.

En el marco protector de la garantía normativa de la igualdad, se garantiza la protección constitucional de la igualdad “en la ley", prohibiendo que el legislador, en uso de sus potestades normativas, o cualquier otro órgano del Estado, establezca diferencias entre las personas y respecto de situaciones o finalidades que tengan una motivación, utilicen medios o bien produzcan un resultado de carácter arbitrario, pues el constituyente no prohibió toda desigualdad ante la ley, sino que, escogiendo una fórmula de otro tipo, optó por establecer un límite a la arbitrariedad, prohibiendo toda discriminación arbitraria;

DECIMOSEXTO. Que, en primer término, entenderemos que es "discriminación arbitraria" toda diferenciación o distinción, realizada por el legislador o por cualquier autoridad pública, que aparezca como contraria a la ética elemental o a un proceso normal de análisis intelectual; en otros términos, que no tenga justificación racional o razonable" (Evans de la Cuadra, Los Derechos Constitucionales, Tomo II, pág. 125);

DECIMOSEPTIMO. Que la garantía jurídica de la igualdad supone, entonces, la diferenciación razonable entre quienes no se encuentren en la misma condición; pues no se impide que la legislación contemple en forma distinta situaciones diferentes, siempre que la discriminación no sea arbitraria ni responda a un propósito de hostilidad contra determinada persona o grupo de personas, o importe indebido favor o privilegio personal o de grupo, debiendo quedar suficientemente claro que el legislador, en ejercicio de sus potestades, puede establecer regímenes especiales, diferenciados y desiguales, siempre que ello no revista el carácter de arbitrario. Cabe agregar que, dentro de dicha tendencia, en materia de derecho comparado se ha declarado que "no toda desigualdad de trato resulta contraria al principio de igualdad, sino aquella que se funda en una diferencia de supuestos de becho injustificados de acuerdo con criterios o juicios de valor generalmente aceptados" (Tribunal Constitucional español, sentencia 128/1987 de 16 de julio de 1983) y que "la igualdad ante la ley consiste en que cuando los supuestos de hecho sean iguales, las consecuencias jurídicas que se extraigan de tales supuestos de hecho han de ser asimismo iguales. Y que deben 
considerarse iguales los supuestos de hecho cuando la introducción en uno de ellos de un elemento o factor que permita diferenciarlo del otro, haya de considerarse falta de un fundamento racional y -sea por ende arbitraria-por no ser tal factor diferencial necesario para la protección de bienes $y$ derechos, buscada por el legislador." (Tribunal Constitucional español, sentencia 103/1983, de 22 de noviembre de 1983);

DECIMOCTAVO. Que, a efectos de establecer el límite entre lo arbitrario y la discrecionalidad, cabe señalar, en primer lugar, siguiendo a la doctrina, la distinción neta entre arbitrariedad y discrecionalidad, es decir, lo que es fruto de la mera voluntad o el puro capricho de lo que, por el contrario, "cuenta con el respaldo -mayor o menor, mejor o peor, es otra cuestión- de una fundamentación que lo sostiene" (Fernández Rodríguez, Tomás-Ramón: Discrecionalidad, Arbitrariedad y Control Jurisdiccional . Palestra Editores, $1^{a}$ edición, Lima, marzo 2006). Así, un primer test para determinar si un enunciado normativo es o no arbitrario es si tiene o no fundamentación de algún tipo, resultando arbitrario aquello que carece de fundamento. Ya superada dicha primera barrera, corresponde calificar la legitimidad de la causa de la diferencia de trato y la legitimidad de la finalidad perseguida; para posteriormente llegar a la coherencia de ellas con los medios utilizados, y finalmente arribar al resultado buscado por el legislador.

Acotando lo ya expuesto, es un lugar común sostener que toda discriminación fundada en raza, sexo o clase es contraria a derecho;

DECIMONOVENO. Que, por otra parte, "debemos entender que un derecho es afectado en su "esencia" cuando se le priva de aquello que le es consustancial, de manera tal que deja de ser reconocible" y debe entenderse que "se impide el libre ejercicio en aquellos casos en que el legislador lo somete a exigencias que lo hacen irrealizable, lo entraban más allá de lo razonable o lo privan de tutela jurídica" (sentencia recaída en la causa Rol $\mathrm{N}^{\circ}$ 43, con respeto al proyecto de Ley Orgánica Constitucional de los Partidos Políticos). En dicha sentencia, este Tribunal señaló que a la ley "debe reconocérsele autonomía suficiente para reglar, en forma prudente y dentro de latitudes razonables" el ejercicio de un derecho. Abundando aún más al respecto, el Tribunal distinguió con exactitud en esa misma sentencia entre lo que es una afectación de un derecho en su esencia y lo que es un impedimento para su libre ejercicio. Es así como en el considerando vigesimoprimero del indicado fallo hizo constar expresamente: "debemos entender que un derecho es afectado en su "esencia" cuando se le priva de aquello que le es consustancial, de manera tal que deja de ser reconocible" y debe entenderse que "se impide el libre ejercicio en aquellos casos en que el legislador lo somete a exigencias que lo hacen irrealizable, lo entraban más allá de lo razonable o lo privan de tutela jurídica.". Así, para estimar violada la garantía del contenido esencial, no basta aumentar el umbral de regulaciones al ejercicio de un derecho, sino que además de ello las exigencias lo deben tornar materialmente irrealizable, o bien entrabarlo más allá de lo razonable, o, por último, las regulaciones legales privarlo de tutela jurídica; 
VIGESIMO. Que, además, en el fallo Rol No 325 (catalíticos), este Tribunal sostuvo que "las disposiciones legales que regulen el ejercicio de estos derechos, deben reunir los requisitos de "determinación” y "especificidad". El primero exige que los derechos que puedan ser afectados se señalen, en forma concreta, en la norma legal; y el segundo requiere que la misma indique, de manera precisa, las medidas especiales que se puedan adoptar con tal finalidad, todo ello sin que puedan los derechos ser afectados en su esencia, ni imponerles condiciones, tributos o requisitos que impidan su libre ejercicio. Siguiendo la línea fijada en la sentencia Rol $N^{\circ} 280$, se "impide su libre ejercicio" cuando el legislador entraba un derecho "más de lo razonable" o lo hace en forma "imprudente". El Tribunal ha sostenido que si bien el legislador tiene autonomía para reglar el ejercicio de un derecho, debe hacerlo "en forma prudente y dentro de latitudes razonables". De esta forma, para limitar de forma constitucionalmente admisible un derecho fundamental sin impedir su libre ejercicio, tales limitaciones deben, primeramente, encontrarse señaladas de forma precisa por la Carta Fundamental; en seguida, debe respetarse el principio de igualdad, esto es, deben imponerse de manera igual para todos los afectados; además, deben establecerse con indudable determinación, tanto en el momento en que nacen, como en el que cesan y, finalmente, deben estar establecidas con parámetros incuestionables, esto es, razonables y justificadas (Rol No 226, considerando $47^{\circ}$ );

VIGESIMOPRIMERO. Que, en este caso, la exclusividad de funciones del juez tributario viene planteada de manera absoluta y sin excepción de ninguna especie. En este orden, cabe señalar que no obstante la habilitación legislativa, los preceptos constitucionales citados aseguran la libertad económica y la libertad de trabajo a toda persona, sin que su núcleo esencial pueda ser tocado.

En tal sentido, cabe señalar que, además de las prescripciones generales, la existencia de la prohibición de ocupar cargos directivos y ejecutivos en instituciones sin fines de lucro y de desarrollar cualquier actividad remunerada no se encuentran en el régimen ordinario de todo juez. En este ámbito se constata una diferencia de trato por parte del legislador, que consiste, al mismo tiempo, en una afectación de la libertad económica y de la libertad de trabajo;

VIGESIMOSEGUNDO. Que para examinar si dichas afectaciones son o no acordes con la Carta Fundamental, debe necesariamente realizarse un examen de proporcionalidad y razonabilidad en torno a ellas, pues los derechos fundamentales constituyen para el derecho contemporáneo el máximo objeto de protección y la finalidad última del sistema jurídico;

VIGESIMOTERCERO. Que es en este sentido que debe estudiarse, por una parte, el motivo de la norma y, por la otra, la necesidad, idoneidad y proporcionalidad de la afectación de las garantías constitucionales en cuestión; 
VIGESIMOCUARTO. Que el artículo 16 del proyecto tiene como objetivo resguardar la imparcialidad del juez y evitar conflictos de interés, asunto que, en principio, se ve como razonable.

Sin embargo, en la medida que el ordenamiento jurídico hace aplicable al juez tributario el régimen de recusaciones e implicancias de la legislación común, el sistema jurídico entrega herramientas suficientes para resguardar dicho valor y cumplir la finalidad ya señalada.

En base a este argumento de contexto, no resulta razonable ni necesario privar a un grupo de personas de sus derechos a la libertad de empresa y a la libertad de trabajo más allá de lo razonable, si existe normativa suficiente para enfrentar el potencial hecho que motiva la prohibición sin afectar derechos fundamentales;

VIGESIMOQUINTO. Que, por otra parte, la finalidad del artículo en comento no puede ser subsumida dentro de las habilitaciones constitucionales para afectar los derechos en cuestión, por lo que la sola existencia del precepto constituye una afectación al núcleo esencial de los mismos al extralimitarse el legislador en su regulación. Ello resulta particularmente relevante, pues el proyecto de ley, en su conjunto, debe ser entendido a la luz del artículo $8^{\circ}$ de la Carta Fundamental, y es en resguardo del principio de probidad que el régimen legal de prohibiciones, inhabilidades, recusaciones e implicancias del juez ordinario es aplicable en este proyecto de ley, lo que hace innecesario y a la vez excesivo lo dispuesto por el artículo 16 del artículo primero antes citado.

VIGESIMOSEXTO. Que, además, el artículo 16 del proyecto de ley bajo control es inconstitucional, al prohibir a "los funcionarios del Tribunal Tributario y Aduanero ocupar cargos directivos, ejecutivos y administrativos en otras entidades, sea que persigan o no fines de lucro", en tanto colisiona con el inciso tercero del número $16^{\circ}$ del artículo 19 de la Constitución, que dispone: "Ninguna ley o disposición de autoridad pública podrá exigir la afiliación a organización o a entidad alguna como requisito para desarrollar una determinada actividad o trabajo, ni la desafiliación para mantenerse en ellos”, además de amenazar directamente el numero $2^{\circ}$ del mismo artículo 19 , que consagra la igualdad ante la ley. En efecto, no se divisa cómo puede constituir una situación de incompatibilidad con un cargo en esta magistratura, el desempeñar actividades en organizaciones que no persiguen fines de lucro, muchas de ellas destinadas a fines altruistas que requieren del concurso de personas idóneas de la comunidad, entre las que se cuentan, sin duda, los magistrados. Además, si no se parte de la presunción jurídica de prevaricación y otros delitos afines, no se entiende cómo se establece esta incompatibilidad sin que ella afecte a los miembros del Congreso Nacional, de cuya independencia depende, entre otros factores, la pulcritud de la formación de la ley que a esta nueva magistratura corresponderá aplicar.

Acordada con el voto en contra de los Ministros señores Jorge Correa Sutil y Francisco Fernández Fredes en relación con lo que se decide en el numeral $3^{\circ}$. Los Ministros disidentes estuvieron por declarar que la última frase del inciso primero, el inciso segundo y el inciso tercero del artículo 12, contenido en el artículo primero del proyecto, no son 
materia de ley orgánica constitucional y, en consecuencia, no corresponde al Tribunal pronunciarse al respecto, por referirse dichas disposiciones a aspectos reglamentarios de la calificación de los jueces tributarios, cuestiones que, a su juicio, no determinan ni la organización, ni las atribuciones de los tribunales que fueren necesarios para la pronta y cumplida administración de justicia en todo el territorio de la República, únicas cuestiones que, en esta materia, la Carta Fundamental reserva a una ley orgánica constitucional. A su juicio, este criterio es el único que se aviene con una larga y sostenida jurisprudencia de este Tribunal que, ya en sentencia de fecha 29 de febrero de 1988 , dictada en la causa Rol N 50 sobre el proyecto de Ley de Municipalidades, declaró: "Que a las normas de interpretación empleadas en los considerandos anteriores para resolver el problema en estudio, frecuente en otras leyes dada la complejidad del tema, hay que recurrir con prudencia, porque, en manera alguna, deben llevarnos a extender el ámbito de aplicación de las leyes orgánicas constitucionales más allá de lo necesario y permitido por la Constitución, ya que el hacerlo privaría a nuestro sistema legal de una equilibrada y conveniente flexibilidad, dado el alto quórum que exige esta clase de leyes para su aprobación, modificación o derogación.” Esa doctrina, con idénticos llamados a no extender el ámbito de las leyes orgánico constitucionales, se encuentra, entre otras, en las sentencias roles 277, 304, 309 y 383.

Acordada, en relación con lo que se decide en el numeral $1^{\circ}$, en cuanto se declara que las expresiones ", en forma fundada y" contenidas en el inciso tercero del artículo $5^{\circ}$ del artículo primero del proyecto remitido son inconstitucionales y deben eliminarse de su texto, con el voto en contra del Ministro señor Jorge Correa Sutil por los siguientes motivos:

PRIMERO. Que concuerdo con el Tribunal que no resulta contrario a la Carta Fundamental que el Consejo de Alta Dirección Pública proponga a la Corte de Apelaciones respectiva una lista de entre cinco y diez nombres para que ésta confeccione la terna de la que el Presidente de la República habrá de nombrar a cada juez tributario. Por los mismos motivos que se contienen en los considerandos $11^{\circ}$ a $19^{\circ}$ del fallo, concurro también a declarar que las expresiones "por una sola vez", que se contienen en el inciso tercero del artículo $5^{\circ}$ son contrarias a la Carta Fundamental, pues no se avienen con la independencia e imparcialidad que deben tener los jueces, particularmente éstos, que van a juzgar los actos de la administración, garantía que forma parte de un justo y racional procedimiento;

SEGUNDO. Que, sin embargo, los motivos expresados, no me convencen para estimar igualmente inconstitucionales las expresiones "en forma fundada", contenidas en el mismo precepto en examen;

TERCERO. Que si se acepta, como hace en este fallo el Tribunal y personalmente comparto, la participación del Consejo para la Alta Dirección Pública para proponer a las Cortes de Apelaciones una lista de nombres para integrar las ternas que se han de formar para la designación de jueces tributarios, no veo por que sería inconstitucional exigir que la Corte de Apelaciones deba fundar el rechazo a esa propuesta; 
CUARTO. Que a mi juicio, obligar a un órgano del Estado, en este caso a una Corte de Apelaciones, a dar razón de sus decisiones, en este caso un rechazo, máxime cuando se trata de un órgano judicial, no resulta contrario a la Carta Fundamental y, por el contrario, es un mecanismo que, en primer lugar, concreta y realiza el principio contenido en el artículo $4^{\circ}$ de la Carta Fundamental, que declara a Chile como una república democrática. Los principios del republicanismo y de la democracia exigen a las autoridades públicas dar fundamento y razón de lo que deciden;

QUINTO. Que en segundo lugar, el proyecto en cuestión, en cuanto exige fundamentar el rechazo de la propuesta, se aviene a y concreta, a mi juicio, lo establecido en el inciso segundo del artículo $8^{\circ}$ de la Carta Fundamental, que dispone que "son públicos los actos y resoluciones de los órganos del Estado, así como sus fundamentos...". La razón del rechazo de uno o más nombres propuestos no haría sino exteriorizar los fundamentos de una resolución de un órgano del Estado;

SEXTO. Que, por último, a mi juicio, la obligación de fundar el rechazo no se opone en nada a que los jueces que se designen cuenten con la independencia e imparcialidad, requeridas, razón que funda la declaración de inconstitucionalidad de la que, en esta parte, disiento.

Acordada con el voto en contra del Ministro señor Jorge Correa Sutil en relación con lo que se decide en el numeral $3^{\circ}$. El Ministro disidente estuvo por declarar que el inciso final del artículo $129 \mathrm{D}$ contenido en el artículo tercero del proyecto, no es materia de ley orgánica constitucional, por referirse únicamente a cuestiones de procedimiento judicial, que la Carta Fundamental no reserva a una ley orgánica constitucional y, por lo tanto, que no le corresponde al Tribunal pronunciarse al respecto.

Redactaron la sentencia los Ministros que la suscriben y las disidencias y prevenciones sus autores.

Devuélvase el proyecto a la Cámara de Diputados, rubricado en cada una de sus hojas por el Secretario del Tribunal, oficiándose.

Regístrese, déjese fotocopia del proyecto y archívese.

Rol No 1.243-2008.

Se certifica que el Ministro señor Enrique Navarro Beltrán concurrió a la vista y al acuerdo del fallo pero no firma por encontrarse ausente con permiso.

Pronunciada por el Excmo. Tribunal Constitucional, integrado por su Presidente don Juan Colombo Campbell y los Ministros señores, Raúl Bertelsen Repetto, Hernán Vodanovic Schnake, Mario Fernández Baeza, Jorge Correa Sutil, Marcelo Venegas Palacios, señora Marisol Peña Torres, señores Enrique Navarro Beltrán y Francisco Fernández Fredes. Autoriza el Secretario del Tribunal Constitucional, don Rafael Larrain Cruz.

\section{COMEnTARio}

Extraño rasero el que establece ahora nuestro Tribunal Constitucional. Después de fallar en la causa rol número 616-2006 en sentencia de fecha 6 se septiembre de 
2007 (rol 616-2006) que no había ningún problema de constitucionalidad en que el Director Regional del Servicio de Impuestos Internos ejerza jurisdicción como tribunal especial situado fuera del Poder Judicial, en la medida que ante él se respeten las garantías del debido proceso que garantiza el artículo $19 \mathrm{n}^{\circ} 3$ inciso $5^{\circ}$ de la Constitución Política de la República, ahora establece que es contrario a la Constitución el hecho de que la Corte de Apelaciones sólo pueda rechazar por una vez y de manera fundada la lista de candidatos que le presenta el Consejo de Alta Dirección Pública para la elaboración de las ternas que dichas cortes deben presentar al Presidente de la República. Y es contrario a la Constitución porque a su juicio esa injerencia del órgano administrativo denominado Consejo de Alta Dirección Pública en la nominación de los jueces y secretarios abogados de los tribunales tributarios y aduaneros no se aviene con las exigencias de independencia e imparcialidad que aseguren el derecho al debido proceso constitucional garantizado en el artículo 19 $\mathrm{n}^{\circ} 3$ inciso quinto CPR.

Extraño rasero si se toma en consideración que el Tribunal Constitucional no había hecho reparo constitucional alguno en sus fallos anteriores en que un órgano de la Administración del Estado ejerciera legítimamente jurisdicción, como es el caso del Director Regional del Servicio de Impuestos Internos. Es decir, no hay problema constitucional alguno en que quien ejerza jurisdicción como tribunal especial sea un funcionario que depende tanto en su designación como en su remoción absolutamente del Ejecutivo (en la cadena jerárquica Presidente de la República, Ministro de Hacienda, Director Nacional del Servicio), pero sí hay problemas de constitucionalidad en el caso de que la Corte de Apelaciones al efectuar la terna que debe ser enviada al Presidente de la República quede limitada para impugnar la lista que le presenta el Consejo de Alta Dirección Pública. Y existe ese problema de constitucionalidad para el Tribunal Constitucional aun cuando en este caso estos jueces estén sometidos a la garantía de la inamovilidad, quizá la herramienta jurídica más poderosa para garantizar la independencia e imparcialidad judicial.

El fallo que se comenta ahora parece romper con el criterio dado hasta esta fecha por el Tribunal Constitucional en el sentido de que "lo propio de la jurisdicción es la función en que consiste y no el órgano que le ejerce" (sentencias rol 472 - 2006 y 616 - 2006). Si lo que define a la jurisdicción, como sostiene el Tribunal Constitucional, es la función que desarrolla, en realidad toda exigencia orgánica que intente asegurar la independencia judicial se desvanece por innecesaria. Mientras ante ese órgano, del tipo que sea, se desarrolle una función amparada por las garantías de un debido proceso, la estructura del órgano es irrelevante.

Pero, a diferencia de otros casos, en este fallo la estructura del órgano sí importa. Tiene así para el tribunal relevancia constitucional quien designa a los jueces de la República para determinar si tenemos una judicatura independiente que con imparcialidad pueda aplicar la ley.

Y las críticas que uno puede formular a este fallo no están dadas por el criterio sustentado, que puede ser compartido, sino que se deben a un cambio de criterio sin que medie una justificación razonable. 
Si para el Tribunal Constitucional es en cierto modo irrelevante constitucionalmente la estructura del órgano que ejerce jurisdicción, como hasta la fecha lo ha sostenido, la ciudadanía no tiene cómo comprender por qué en este caso sí importa cómo se generan los jueces tributarios y aduaneros. Y lo que es más grave, la ciudadanía y desde luego los actores políticos podrían quedarse con la idea de que si el problema de constitucionalidad se genera en el procedimiento de confección de las ternas por las Cortes de Apelaciones, entonces una medida legítima alternativa podría haber consistido en que el legislador no hubiese considerado a esas cortes en el procedimiento de designación de los jueces, pudiendo el Consejo de Alta Dirección Pública proponerle una lista directamente al Presidente de la República para proceder al nombramiento. Después de todo, la designación de jueces como resorte exclusivo del Ejecutivo no ha sido cuestionada por el Tribunal Constitucional.

Y todo lo anterior parece indicar que a juicio del Tribunal Constitucional hay dos tipos de jueces especiales situados fuera del Poder Judicial en nuestro sistema jurídico. Aquellos que forman parte de tribunales de justicia que con exclusividad desarrollan la función jurisdiccional (como los de los Tribunales Tributarios y Aduaneros recientemente creados por la ley) y aquellos que además de funciones jurisdiccionales desarrollan otras funciones, como administrativas o políticas (como los Directores Regionales del Servicio de Impuestos Internos). Para los primeros el nombramiento tiene que ser compartido entre el Poder Judicial y el Ejecutivo. Para los segundos basta la designación administrativa o ejecutiva sin que intervenga el Poder Judicial. Eso es lo que uno logra deducir de este fallo del Tribunal Constitucional.

El problema es que no hay disposición constitucional alguna que nos permita construir este "sistema judicial". Este problema, utilizando un lenguaje muy común en medios periodísticos pero no sólo periodísticos, podría ser calificado como "no menor", si tenemos presente que estamos hablando de Derecho Constitucional orgánico. 